\title{
Karakteristik Antosianin dari Kulit Buah Nipah (Nypa frutican) sebagai Pewarna Alami dengan Metode Soxhletasi
}

\section{Characteristic of Anthocyanin from Nypa Fructican Husk as Natural Dyes by using Soxhletation Method}

\author{
Putri Herfayati, Setiaty Pandia, Halimatuddahliana Nasution* \\ Departemen Teknik Kimia, Fakultas Teknik, Universitas Sumatera Utara, Jalan Almamater Kampus USU, \\ Medan, 20155, Indonesia \\ *Email: halimatuddahliana@usu.ac.id
}

\begin{abstract}
Abstrak
Antosianin merupakan pigmen alami pemberi warna merah pada kulit buah nipah (Nypa fructican). Ekstraksi antosianin menggunakan metode soxhletasi dengan variabel bebas jenis pelarut (aquadest dan etanol dengan asam sitrat 3\% (b/v)) dan waktu ekstraksi (30, 45 dan 60 menit). Penelitian ini bertujuan untuk mengetahui jenis pelarut dan waktu ekstraksi terbaik untuk ekstraksi antosianin dari kulit buah nipah. Parameter penelitian meliputi analisis kualitatif dan kuantitatif antosianin (rendemen ekstrak, total konsentrasi antosianin, intensitas warna, aktivitas antioksidan dan letal toksisitas) dari ekstrak kulit buah nipah. Hasil penelitian secara kualitatif dan kuantitatif menunjukkan bahwa ekstrak kulit buah nipah mengandung antosianin dengan rendemen ekstrak tertinggi diperoleh menggunakan pelarut etanol-asam sitrat 3\% pada waktu ekstraksi 60 menit sebesar 0,546 gram/gram. Total antosianin tertinggi diperoleh menggunakan pelarut etanol-asam sitrat $3 \%$ pada waktu ekstraksi 30 menit sebesar 226,036 mg/L. Intensitas warna tertinggi diperoleh menggunakan pelarut etanol-asam sitrat 3\% pada waktu ekstraksi 30 menit sebesar 0,925 . Aktivitas antioksidan terkuat $\left(\mathrm{IC}_{50}\right)$ terkuat diperoleh menggunakan pelarut aquadest-asam sitrat 3\% pada waktu ekstraksi 30 menit sebesar 3,569 ppm. Aktivitas toksisitas terkuat ( $\mathrm{LC}_{50}$ ) diperoleh pada pelarut etanol-asam sitrat 3\% sebesar 80,023 ppm.
\end{abstract}

Kata kunci: antosianin, ekstraksi soxhletasi, kulit buah nipah, pewarna alami

\begin{abstract}
Anthocyanin is a natural pigment that gives red colour on Nipah husk (Nypa fructican) extract. Extraction of anthocyanin compounds used the soxhletation method with independent variables were the type of solvent (aquadest and ethanol with citric acid 3\% (w/v)) and extraction time (30, 45 and 60 minutes). This study aims to determine the best type of solvent and extraction time used for extraction of anthocyanin from Nipah husk. The parameters in this study include qualitative and quantitative analysis of anthocyanin (extract yield, total anthocyanin concentration, color intensity, antioxidant activity and analysis of toxicity) from Nipah husk extract. The results qualitatively and quantitatively indicate that Nipah husk extract had anthocyanin content with the highest extract yield was obtained using ethanol-citric acid 3\% solvent at 60 minutes extraction time of 0.546 gram / gram. The highest total anthocyanin was obtained using ethanol-citric acid 3\% solvent at 30 minutes extraction time of $226.36 \mathrm{mg} / \mathrm{L}$. The highest color intensity was obtained using ethanol-citric acid 3\% solvent at 30 minutes extraction time of 0.925 . The strongest antioxidant activity $\left(\mathrm{IC}_{50}\right)$ was obtained using $3 \%$ aquadest-citric acid solvent at 30 minutes extraction time of $3.569 \mathrm{ppm}$. The strongest toxicity activity $\left(\mathrm{LC}_{50}\right)$ in ethanol-citric acid 3\% solvent was $80.023 \mathrm{ppm}$.
\end{abstract}

Keywords: anthocyanin, soxhletation extraction, nipah husk, natural dyes

\section{Pendahuluan}

Meningkatnya kesadaran manusia akan dampak buruk dari produk sintetis pada kesehatan telah membawa perubahan aturan penggunaan pewarna dalam makanan dan kosmetik. Zat pewarna sintetis terbukti lebih murah dan menguntungkan dari segi ekonomis. Namun penggunaannya dapat menyebabkan toksik dan karsinogenik, karena kandungan logam berat dalam pewarna sintetis tidak dapat dihancurkan oleh sistem pencernaan manusia dan akan terakumulasi di dalam tubuh. Selama dekade terakhir semakin banyak aspek baru dimasukkan ke dalam penilaian produk sintetis namun setiap argumen baru yang dimasukkan memperkuat posisi pewarna alami [1][2]. Dampak negatif dari zat pewarna sintetis tersebut menimbulkan keinginan konsumen untuk kembali pada 
penggunaan pewarna alami. Pewarna alami merupakan alternatif pewarna yang tidak toksik, dapat diperbaharui (renewable), mudah terdegradasi dan ramah lingkungan. Sumber pewarna alami dapat berasal dari alam seperti tumbuhan dan hewan [3].

Salah satu alternatif bahan baku untuk pembuatan pewarna alami adalah kulit buah Nipah. Nipah mengandung komponen fenolik, flavonoid dan tanin yang merupakan indikator antioksidan sebagai metabolit defensif yang melawan spesies oksigen reaktif [4][5]. Fenolik memberikan gambaran keberadaan antosianin dalam kulit nipah. Antosianin termasuk dalam golongan flavonoid yang merupakan bagian dari kelompok besar senyawa polifenolik [6]. Ekstraksi merupakan angkah awal dalam mengisolasi komponen aktif bahan alami. Salah satu metode ekstraksi yang sangat umum adalah soxhletasi [7]. Ekstraksi soxhletasi umumnya dilakukan dalam waktu yang lebih singkat dan berlangsung pada suhu titik didih pelarut [8]. Waktu ekstraksi penting untuk ditinjau dalam ekstraksi komponen aktif dikarenakan waktu ekstraksi yang lama dalam ekstraksi soxhlet akan meningkatkan kemungkinan degradasi termal [9].

Penelitian-penelitian terdahulu tentang nipah oleh Azis dan Jack (2015), Radam dan Erni (2016), Lovly dan Merlee (2017) dan Sabri et. al (2018) hanya sebatas sampai identifikasi senyawa fenolik [4][5][10][11]. Hingga saat ini, tidak ada informasi yang telah didokumentasikan tentang karakteristik antosianin dari ekstrak kulit buah nipah. Antosianin bersifat termolabil, sehingga pemilihan waktu yang tepat dalam ekstraksi komponen ini sangat penting. Penelitian ini bertujuan untuk mengidentifikasi antosianin dan menentukan waktu ekstraksi terbaik yang digunakan dalam ekstraksi antosianin dari kulit buah nipah terhadap karakteristik antosianin yang diperoleh dari ekstraksi dengan dua jenis pelarut non toksik yang dipilih yaitu etanol dan aquadest.

\section{Teori}

Nipah (Nypa frutican) adalah satu-satunya jenis palem yang termasuk komoditas mangrove. Nipah mengandung minyak, tepung, gula dan lainnya. Di Indonesia, luas hutan nipah alami mencapai 4.237.000 hektar. Buah nipah berbentuk bulat telur dan gepeng dengan 2-3 rusuk, berwarna coklat kemerahan, berkelompok membentuk bola berdiameter sekitar $30 \mathrm{~cm}$ (Gambar 1). Buah nipah muda teksturnya lembek, berwarna bening dan berwarna putih seperti kelapa jika sudah tua. Nipah kaya akan fenol dan senyawa flavonoid yang dihubungkan dengan senyawa antioksidan [5][12] [13].

Studi terbaru yang dilakukan oleh Negara Malaysia mengenai aktivitas antioksidan dari cuka $N$. fruticans menunjukkan bahwa nipah kaya akan antioksidan [11]. Prasad, dkk (2013) melaporkan bahwa aktivitas antioksidan dari bagian buah nipah muda dan tua sangat berhubungan dengan kandungan fenoliknya. Banyak senyawa fenolik dan flavonoid yang diidentifikasi dari endosperm dan mesoperm nipah seperti asam klorogenik, asam protocatechuic dan kaemprefol [14].

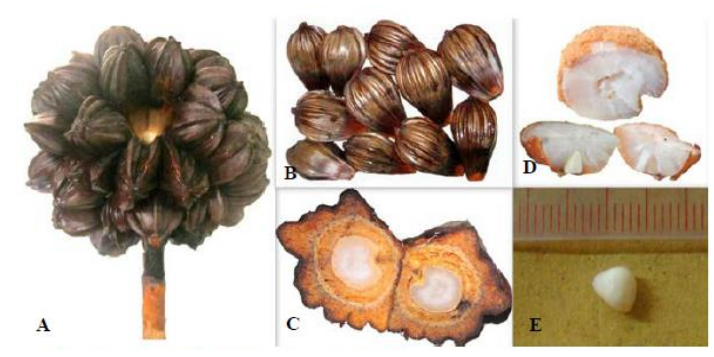

Gambar 1. A. Buah nipah; B. Nipah tua; C. Endosperm nipah dengan kulit; D. Endosperm tanpa kulit; E. Zigot embrio nipah [14]

Antosianin termasuk ke dalam substansi fenolik yang secara luas terdapat dalam tanaman yang memberikan warna biru, merah atau ungu. Dalam media asam, antosianin berwarna merah, ungu dalam larutan netral, dan biru hijau dalam larutan basa. Stabilitas antosianin bergantung pada $\mathrm{pH}$, cahaya, suhu dan struktur kimianya. Struktur antosianin dapat dilihat pada Gambar 2. Antosianin dicirikan oleh gugus hidroksil pada posisi 4' dan 7, dan gula pada posisi 3 (monoglikosida) atau 3 dan 5 (diglikosida). Sampai saat ini, lebih dari 540 pigmen antosianin telah diidentifikasi di alam yang sebagian besar variasi struktural berasal dari substitusi glikosidik pada posisi ketiga dan kelima juga asilasi residu gula dengan asam organik. Senyawa antosianin yang paling banyak ditemukan adalah pelargonidin (oranye-merah), peonidin (merah), sianidin (merah-ungu), malvidin (ungu tua), petunidin (ungu), dan delfinidin (biru-ungu) [1][15][16].

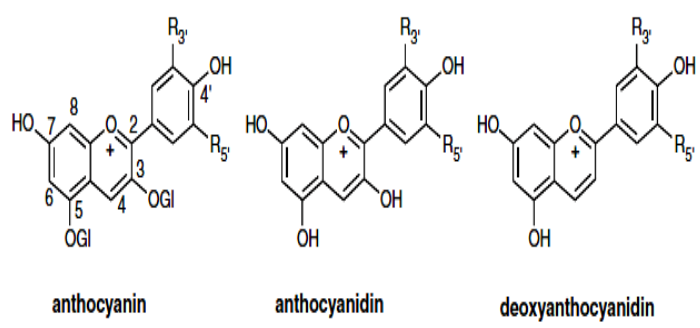

Gambar 2. Struktur molekuler antosianin (OGI = glikosida), antosianidin dan deoksiantosianin [1] 
Disamping memberi pengaruh warna, antosianin juga memiliki nilai medis sebagai anti diabetes, anti kanker, anti radang, anti mikroba, anti obeses dan juga mencegah penyakit kardiovaskular. Aktivitas antioksidan antosianin lebih besar 2-6 kali dibandingkan antioksidan umum lain seperti asam askorbat. Antosianin biasa diaplikasikan sebagai pewarna makanan nonminuman juga makanan penutup seperti gelatin, isi buah dan penganan (gula-gula) tertentu [15][16].

\section{Metodologi Penelitian}

Pengumpulan bahan baku

Kulit buah nipah berasal dari Desa Indrayaman (Kec. Talawi, Kab. Batubara).

\section{Pre-treatment bahan baku}

Kulit buah nipah dicuci dan dikecilkan ukurannya menjadi $\pm 0,5 \mathrm{~cm}$ lalu dihaluskan dengan blender.

\section{Ekstraksi Metode Soxhletasi}

Ekstraksi soxhletasi meliputi ekstraksi untuk analisa kualitatif dan kuantitatif serta untuk uji toksisitas. Ekstraksi dilakukan dengan variabel tetap massa sampel (25 gram) dan rasio bahan:pelarut $(1: 10(\mathrm{~b} / \mathrm{v}))$ dengan variabel berubah jenis pelarut (aquadest dan etanol dengan asam sitrat 3\%) dan waktu ekstraksi (30, 45 dan 60 menit) untuk analisa kualitatif dan kuantitatif, sedangkan untuk uji toksisitas dilakukan hingga pelarut pada timbel soxhlet bening. Hasil ekstraksi dipekatkan dengan rotary evaporator dan di analisis kualitatif metode asam - basa dengan penambahan $\mathrm{HCl} 2 \mathrm{M}$ dan $\mathrm{NaOH} 2 \mathrm{M}$ serta kuantitatif (rendemen ekstrak, total antosianin, intensitas warna dan aktivitas antioksidan metode DPPH) menggunakan spektrofotometer Uv-Vis. Uji toksisitas menggunakan metode brine shrimp lethality test dengan media bioidikator Artemia dengan variabel tetap jumlah bioindikator (10 ekor), usia bioindikator (14 hari bertujuan agar mempermudah pengamatan kematian larva) dan volume media uji $(10 \mathrm{ml})$, sedangkan variabel berubah adalah waktu pengamatan kematian bioindikator I $\Delta \mathrm{t}=1$ jam selama 6 jam dan II $\Delta \mathrm{t}=$ 6 jam selama 24 jam serta konsentrasi larutan uji (1000, 100, 10 dan 0 ppm).

\section{Hasil dan Pembahasan \\ Analisis Antosianin Secara Kualitatif}

Analisis kualitatif bertujuan untuk mengidentifikasi keberadaan antosianin pada ekstrak kulit buah nipah. Hasil analisis kualitatif dapat dilihat pada Gambar 3 dan Tabel 1 dimana dengan penambahan $\mathrm{HCl} 2 \mathrm{M}$ terbentuk warna merah pada ekstrak dengan pelarut aquadest dan etanol. Penambahan $\mathrm{NaOH} 2 \mathrm{M}$ mengubah warna merah menjadi warna hijau kebiruan pada ekstrak dengan pelarut aquadest dan etanol.

Perubahan warna ekstrak kulit buah nipah dari merah (kondisi asam) menjadi hijau kebiruan (kondisi basa) memperlihatkan bahwa terdapat antosianin dalam ekstrak kulit buah nipah. Warna merah terbentuk oleh kation flavilium, dimana jumlah gugus metoksi dalam struktur antosianin lebih dominan dibandingkan gugus hidroksi. Pada $\mathrm{pH}$ netral berwarna keunguan dan $\mathrm{pH}$ basa berubah menjadi hijau kebiruan disebabkan struktur karbinol pseudobase. Ketika $\mathrm{pH}$ semakin tinggi struktur kalkon terbentuk yang menyebabkan antosianin kehilangan warna merahnya diakibatkan terbentuknya anion quinonoidal [16][18].

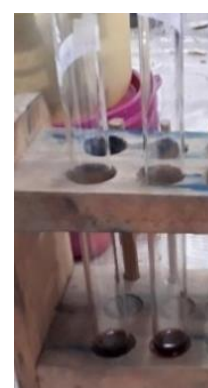

(a)

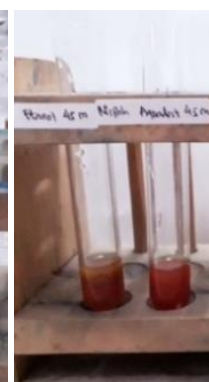

(b)

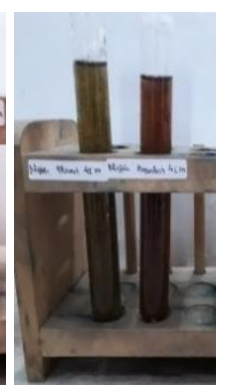

(c)
Gambar 3. (a) Ekstrak Pekat; (b) Penambahan HCl $2 \mathrm{M}$; (c) Penambahan Larutan $\mathrm{NaOH} 2 \mathrm{M}$

Tabel 1. Analisis Kualitatif Ekstrak Kulit Buah Nipah

\begin{tabular}{|c|c|c|c|c|}
\hline Pelarut & Reaksi & Karakter Warna Antosianin & Warna & Hasil \\
\hline \multirow{2}{*}{ Aquadest } & Ekstrak + HCl 2 M & Merah mantap / tidak pudar & Merah pekat & Positif $(+)$ \\
\cline { 2 - 5 } & Ekstrak + NaOH 2 M & Berubah menjadi hijau biru & Hijau gelap & Positif $(+)$ \\
\hline \multirow{2}{*}{ Etanol } & Ekstrak + HCl 2 M & Merah mantap / tidak pudar & Merah bata & Positif $(+)$ \\
\cline { 2 - 5 } & Ekstrak + NaOH 2 M & Berubah menjadi hijau biru & Kehijauan & Positif $(+)$ \\
\hline
\end{tabular}

\section{Pengaruh Waktu dan Jenis Pelarut Terhadap Rendemen Ekstrak Kulit Buah Nipah}

Pada Gambar 4 dapat dilihat rendemen ekstrak kulit buah nipah pada waktu ekstraksi 30 ,
45, dan 60 menit dengan pelarut aquadest sebesar 0,$178 ; 0,299 ;$ dan 0,310 gram/gram dan pelarut etanol sebesar 0,446; 0,497; dan 0,546 gram/gram. Hal ini menunjukkan bahwa semakin lama waktu 
ekstraksi maka semakin banyak ekstrak diperoleh yang meningkatakan nilai rendemen.

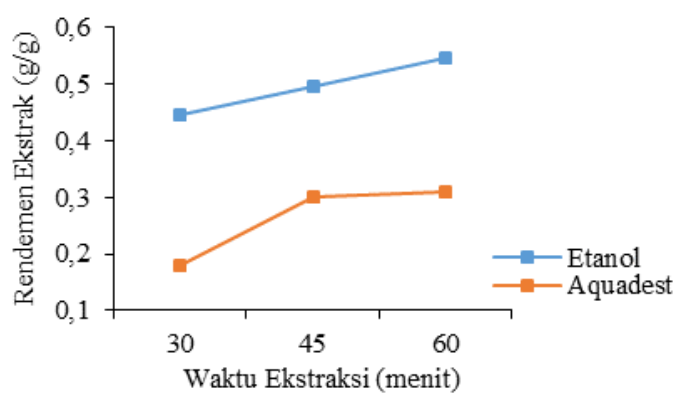

\section{Gambar 4. Pengaruh Waktu dan Jenis Pelarut Terhadap Rendemen Ekstrak Kulit Nipah}

Berdasarkan teori, peningkatan rendemen dikarenakan waktu ekstraksi yang lama menyebabkan terpenuhinya waktu kontak antara matriks bahan dan pelarut sehingga lebih banyak senyawa target yang terlarut dengan pelarut alkohol lebih baik digunakan untuk mengekstrak habis komponen aktif dari golongan fenolik [19][12].

Meskipun bukan berarti rendemen yang semakin meningkat menghasilkan antosianin yang meningkat pula, karena ada senyawa pengotor lain yang ikut terekstrak dan terkonsentrasi dalam ekstrak antosianin seperti gula, asam organik, senyawa fenol lain selain antosianin [19]. Sehingga, berdasarkan Gambar 4 dapat disimpulkan bahwa rendemen ekstrak kulit buah nipah terbaik diperoleh pada perlakuan dengan pelarut etanol dan waktu ekstraksi 60 menit.

\section{Pengaruh Waktu dan Jenis Pelarut Terhadap Total Antosianin Ekstrak Kulit Buah Nipah}

Pada Gambar 5 diperoleh hasil total antosianin dalam ekstrak kulit buah nipah pada waktu ekstraksi 30, 45, dan 60 menit dengan pelarut aquadest sebesar 206,348; 173,705; dan $101,491 \mathrm{mg} / \mathrm{L}$ dengan pelarut etanol pada waktu ekstraksi 30, 45, dan 60 menit sebesar 226,036; 126,484 dan $84,764 \mathrm{mg} / \mathrm{L}$. Hal ini memperlihatkan bahwa peningkatan waktu ekstraksi menyebabkan penurunan jumlah total antosianin.

Berdasarkan teori, ada batasan tertentu bagi pelarut untuk melarutkan solute yang terdapat dalam bahan baku yang diekstrak sekalipun waktu ekstraksi diperpanjang solute dalam bahan baku sudah tidak ada. Sehingga yang terjadi selama penambahan waktu hanyalah pemaparan panas pada hasil ekstraksi, dimana akibat dari waktu pemaparan panas yang terlalu lama ini adalah peningkatan resiko degradasi senyawa antosianin [20]. Hal yang sama diungkapkan oleh Muangrat dan Phanat (2018) dan Laksanalamai (2015) yang menyatakan bahwa total antosianin lebih tinggi diperoleh pada waktu ekstraksi 15 menit dari pada 30, 45, dan 60 menit dikarenakan peningkatan waktu menyebabkan degradasi atau kehilangan antosianin [21][22]. Nayal dan Onkar (2017) dan Ruiz et. al (2017) bahwa total antosianin menurun secara signifikan dengan meningkatnya waktu pemanasan ketika menggunakan metode soxhlet diakibatkan degradasi antosianin [23][24]. Qadariyah et. al (2017) menyatakan total antosianin menurun setelah ekstraksi lebih dari 20 menit [25]. Sedangkan Klavins et. al (2017) menyatakan waktu ekstraksi optimal antosianin adalah 15 sampai 25 menit [26].

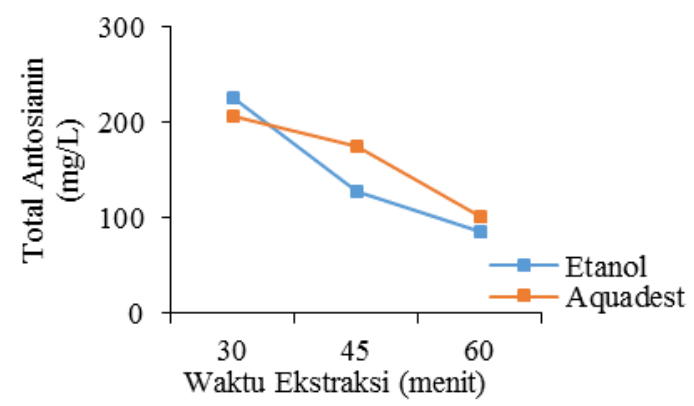

Gambar 5. Pengaruh Waktu dan Jenis Pelarut Terhadap Total Antosiain Ekstrak Kulit Nipah

Sehingga berdasarkan Gambar 5 dapat disimpulkan bahwa total antosianin ekstrak kulit buah nipah terbaik diperoleh dengan pelarut etanol pada waktu ekstraksi 30 menit.

\section{Pengaruh Waktu dan Jenis Pelarut Terhadap Intensitas Warna Ekstrak Kulit Buah Nipah}

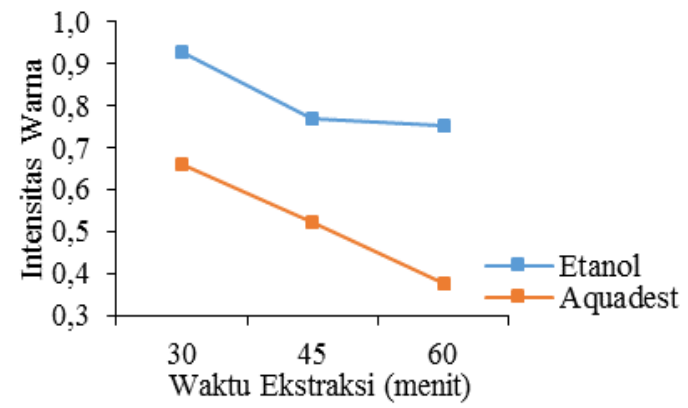

Gambar 6. Pengaruh Waktu Ekstraksi dan Jenis Pelarut terhadap Intensitas Warna Ekstrak Kulit Buah Nipah

Pada Gambar 6 diperoleh hasil intensitas warna ekstrak kulit buah nipah pada waktu ekstraksi 30, 45, dan 60 menit dengan pelarut aquadest masing-masing sebesar 0,659; 0,521; dan 0,378 dan dengan pelarut etanol pada waktu ekstraksi 30, 45, dan 60 menit masing-masing 
sebesar 0,925; 0,768; dan 0,753. Hal ini memperlihatkan bahwa semakin lama waktu ekstraksi menyebabkan intensitas warna antosianin menurun.

Berdasarkan teori, waktu pemanasan yang lama menghasilkan nilai absorbansi warna yang menurun dikarenakan semakin lama waktu pemanasan mengakibatkan pigmen antosianin terdekomposisi sehingga terjadi pemucatan dan nilai absorbansinya menurun. Pigmen antosianin bersifat tidak stabil terhadap pemanasan. Ekstraksi selama 30 menit pada suhu tertentu memicu degradasi antosianin lebih cepat dibandingkan ekstraksi tanpa pemanasan [27]. Hal serupa diungkapkan oleh Ali et. al (2013) dimana semakin lama waktu pemanasan maka semakin lama antosianin terpapar panas sehingga derajat kecerahan semakin menurun disebabkan antosianin terekstrak memiliki kecenderungan berwarna pekat sehingga warna yang dihasilkan mengalami penurunan tingkat kecerahan [28]. Sehingga, berdasarkan Gambar 6. dapat disimpulkan bahwa intensitas warna ekstrak kulit buah nipah terbaik diperoleh dengan pelarut etanol pada waktu ekstraksi 30 menit.

\section{Pengaruh Waktu dan Jenis Pelarut Terhadap Aktivitas Antioksidan Ekstrak Kulit Nipah}

Pada Gambar 7 dapat dilihat bahwa persen inhibisi ekstrak kulit buah nipah pada kedua pelarut aquadest dan etanol dipengaruhi oleh konsentrasi larutan uji. Semakin banyak ekstrak kulit buah nipah yang terdapat dalam larutan uji maka semakin besar konsentrasi larutan uji dan berpengaruh pada semakin meningkatnya persen inhibisi.

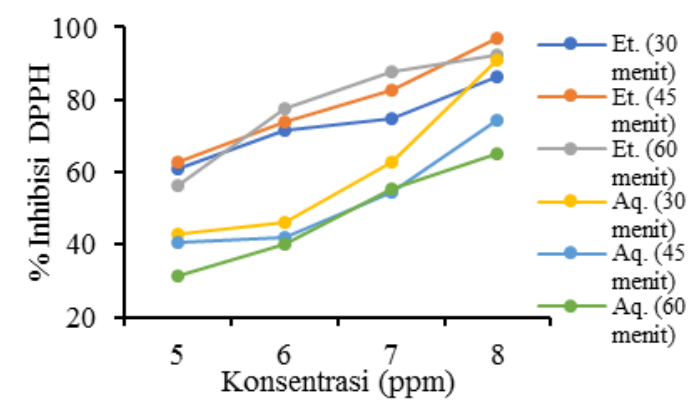

Gambar 7. Pengaruh Konsentrasi Larutan Ekstrak Kulit Buah Nipah Terhadap Persen Inhibisi

Berdasarkan teori, persen inhibisi berpola linier dimana semakin tinggi konsentrasi ekstrak maka nilai persen inhibisi semakin tinggi. Konsentrasi yang lebih tinggi akan menunjukkan aktivitas antioksidan yang lebih tinggi [29]. Data persen inhibisi dalam metode DPPH digunakan untuk menentukan nilai aktivitas antioksidan yang dinyatakan dalam bentuk $\mathrm{IC}_{50}$. Nilai $\mathrm{IC}_{50}$ merupakan konsentrasi larutan sampel yang dibutuhkan untuk mereduksi DPPH sebesar $50 \%$. Semakin kecil nilai $\mathrm{IC}_{50}$ berarti aktivitas antioksidannya semakin tinggi [12].

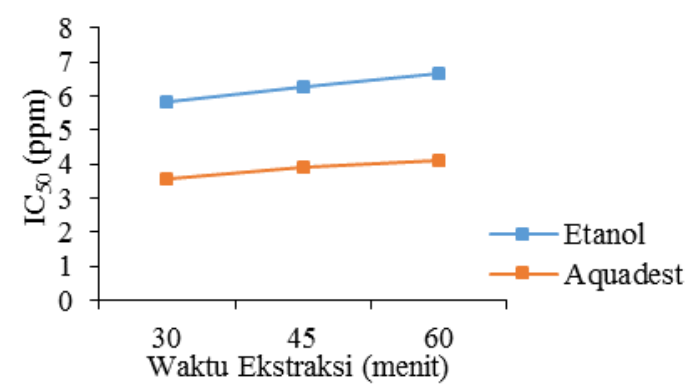

\section{Gambar 8. Pengaruh Waktu dan Jenis Pelarut Ekstraksi Terhadap Aktivitas Antioksidan}

Pada Gambar 8 diperoleh nilai aktivitas antioksidan ekstrak kulit buah nipah pada waktu ekstraksi 30, 45, dan 60 menit masing-masing dengan pelarut aquadest sebesar 3,569; 3,887; dan $4,096 \%$ dan pelarut etanol sebesar 5,832; 6,251 dan 6,677 \%. Hal ini memperlihatkan bahwa semakin lama waktu ekstraksi maka semakin menurun aktivitas antioksidannya ditandai dengan nilai $\mathrm{IC}_{50}$ yang meningkat.

Perbedaan nilai $\mathrm{IC}_{50}$ ini disebabkan oleh perbedaan jumlah antioksidan yang terkandung didalam ekstrak. Penurunan aktivitas antioksidan terjadi akibat kerusakan antosianin yang bersifat labil terhadap pemanasan yang lama [30]. Berdasarkan pelarut, kemampuan menghambat radikal bebas paling tinggi tampak pada ekstrak dengan pelarut aquadest yang menunjukkan daya hambat besar disebabkan senyawa antosianin memiliki banyak gugus penangkap radikal bebas lebih aktif terhadap radikal bebas yang terdapat dalam pelarut aquadest dibandingkan dengan pelarut alcohol [31]. Kopjar et. al (2014) menyatakan aktivitas antioksidan lebih tinggi berada pada ekstrak dengan pelarut aquadest dibandingkan dengan etanol dengan aktivitas antioksidan keseluruhan berada di urutan metanol > air > etanol > etil asetat dalam ekstrak [32].

\section{Analisis Toksisitas Ekstrak Kulit Nipah}

Suatu senyawa dikategorikan sangat toksik jika nilai $\mathrm{LC}_{50}$ kurang dari 30 ppm, toksik jika nilai $\mathrm{LC}_{50}$ 30-1000 ppm, dan tidak toksik jika nilai $\mathrm{LC}_{50}$ di atas $1000 \mathrm{ppm}$. Tingkat toksisitas tersebut menunjukkan potensi aktivitasnya sebagai antikanker dimana semakin kecil nilai $\mathrm{LC}_{50}$ maka semakin toksik suatu senyawa dan berpotensi sebagai antikanker [33]. Nilai LC $_{50}$ dari ekstrak kulit buah nipah dapat dilihat pada Tabel 2. 
Tabel 2. Hasil Analisis Toksisitas Metode Brine Shrimp Lethality Test

\begin{tabular}{|c|c|c|}
\hline Pelarut & Persamaan linier & $\mathrm{LC}_{50}(\mathrm{ppm})$ \\
\hline Aquadest & $\mathrm{y}=2,9612 \mathrm{x}-1,404$ & 145,4365 \\
\hline Etanol & $\mathrm{y}=2,4634 \mathrm{x}+0,311$ & 80,0234 \\
\hline
\end{tabular}

Berdasarkan Tabel 2 dapat disimpulkan bahwa ekstrak kulit buah nipah dapat digunakan sebagai pewarna alami dalam berbagai produk pangan dengan penggunaan $145,436 \mathrm{ppm}(145,436$ $\mathrm{mg} / \mathrm{L})$ per $\mathrm{kg}$ produk pangan untuk ekstrak yang diperoleh dengan pelarut aquadest dan 80,023 ppm $(80,023 \mathrm{mg} / \mathrm{L})$ per $\mathrm{kg}$ produk pangan untuk ekstrak yang berasal dari pelarut etanol.

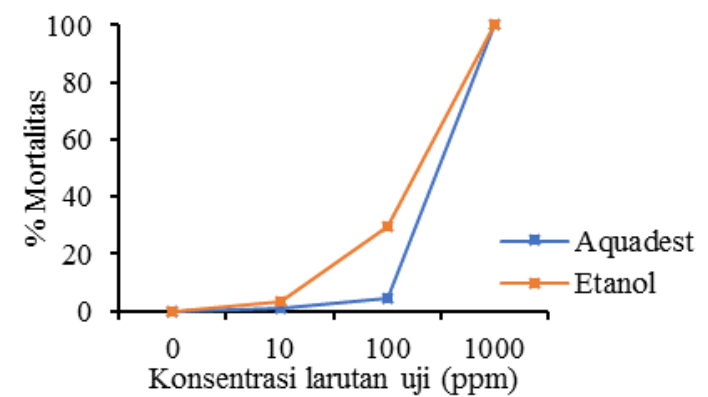

\section{Gambar 9. Pengaruh Konsentrasi Larutan Uji Terhadap Persen Mortalitas}

Gambar 9 memperlihatkan bahwa nilai mortalitas meningkat dengan meningkatnya konsentrasi larutan uji, hal ini sesuai dengan pernyataan Sabri et. al (2018) dimana laju mortalitas larva meningkat dengan meningkatnya konsentrasi larutan uji [11]. Sedangkan nilai LC $_{50}$ untuk masing-masing pelarut aquadest adalah 145,4365 ppm dan pelarut etanol adalah 80,0234 ppm yang dikategorikan bersifat toksik. Sifat sitotoksik dari ekstrak dikarenakan ekstrak mengandung golongan flavonoid yang mengikat gugus glikosida yang mengandung gugus $\mathrm{OH}$. Gugus $\mathrm{OH}$ lebih aktif untuk membunuh dan menghambat pertumbuhan Artemia dengan merusak struktur dinding sel, menghambat kerja enzim, menghambat fungsi membran sel, sintesis protein dan asam nukleat [34]. Toksisitas antosianin belum banyak dipelajari. Komite FAO/WHO bagian zat adiktif makanan menetapkan asupan harian antosianin diizinkan sebesar 2,5 mg/kg berat badan per hari. Sedangkan otoritas keamanan makanan China belum menemukan efek toksik dari antosianin pada tikus dan kelinci percobaan selama 15-90 hari. Penelitian pada manusia menunjukkan bahwa antosianin cepat diserap dan muncul dalam aliran darah beberapa menit setelah dikonsumsi [35]. Sedangkan untuk standar konsumsi harian antosianin di Indonesia mengikuti standar SNI yang diatur dalam KBPOM RI Nomor 37 Tahun 2013 diperbolehkan dalam rentang $0-2,5 \mathrm{mg} / \mathrm{kg}$ berat badan. Sebagai pewarna adiktif pangan 100$10000 \mathrm{mg} / \mathrm{kg}$ berat bahan pangan [36].

\section{Kesimpulan}

Ekstrak kulit buah nipah positif mengandung antosianin ditandai dengan perubahan warna ekstrak menjadi merah pada larutan asam dan hijau pada larutan basa. Rendemen ekstrak tertinggi dan aktivitas antioksidan terkuat diperolehh menggunakan pelarut etanol-asam sitrat $3 \%$ dengan waktu ekstraksi 60 menit sebesar 0,546 gram/gram dan nilai $\mathrm{IC}_{50} \quad 6,677 \mathrm{ppm}$. Total antosianin dan intensitas warna tertinggi diperoleh dengan menggunakan pelarut etanol-asam sitrat $3 \%$ pada waktu ekstraksi 30 menit sebesar 226,036 $\mathrm{mg} / \mathrm{L}$ dan 0,925. Aktivitas toksisitas terkuat diperoleh dengan nilai LC $_{50}$ sebesar 80,023 ppm atau setara dengan $0,080 \%$ pada pelarut etanolasam sitrat $3 \%$.

\section{Daftar Pustaka}

[1] T. Bechtold and R. Mussak, Handbook of Natural Colorants. 2009.

[2] E. Paryanto, Kwartiningsih, W. A. W, S. H. Pranolo, R. Hidayat, and I. R. S, "Pengambilan Zat Warna Alami dari Buah Mangrove Spesies Rhizophora Mucronata untuk Pewarna Batik Ramah Lingkungan," $J$. Purifikasi, vol. 15, no. 1, pp. 33-40, 2015.

[3] Yernisa, E. G. Said, and K. Syamsu, "Aplikasi Pewarna Bubuk Alami dari Ekstrak Biji Pinang (Areca Cathechu L.) pada Pewarnaan Sabun Transparan," J. Teknol. Ind. Pertan., vol. 23, no. 3, pp. 190-198, 2013.

[4] R. R. Radam and E. Purnamasari, "Uji Fitokimia Senyawa Kimia Aktif Akar Nipah (Nyfa Fruticans Wurmb) Sebagai Tumbuhan Obat di Kalimantan Selatan," J. Hutan Trop., vol. 4, no. 1, p. 28, 2017, doi: 10.20527/jht.v4i1.2879.

[5] L. M. S. and M. T. M. V., "In Vitro Bioactivity and Phytochemical Characterization of Nypa fruticans. Wurmb : a Mangrove from Kerala," Int. J. Res. J. Biol. Sci., vol. 6, no. 6, pp. 42-52, 2017.

[6] A. Masci, A. Coccia, E. Lendaro, L. Mosca, P. Paolicelli, and S. Cesa, "Evaluation of Different Extraction Methods from Pomegranate Whole Fruit or Peels and The Antioxidant and Antiproliferative Activity of The Polyphenolic Fraction," Food Chem., vol. 202, pp. 59-69, 2016, doi: 10.1016/j.foodchem.2016.01.106.

[7] A. P. Kristijarti and A. Arlene, "Isolasi Zat 
Warna Ungu pada Ipomoea batatas Poir dengan Pelarut Air," Rekayasa Sist. Ind., vol. 1, no. 3, pp. 1-31, 2012.

[8] I. Y. Bae, J. S. An, I. K. Oh, and H. G. Lee, "Optimized Preparation of Anthocyanin-Rich Extract From Black Rice and Its Effects on In-vitro Digestibility," Food Sci. Biotechnol., vol. 26, no. 5, pp. 1415-1422, 2017, doi: 10.1007/s10068-017-0188-x.

[9] Q. W. Zhang, L. G. Lin, and W. C. Ye, "Techniques for Extraction and Isolation of Natural Products: a Comprehensive Review," Chinese Med. (United Kingdom), vol. 13, no. 1, pp. 1-26, 2018, doi: 10.1186/s13020-0180177-x.

[10] A. Aziz and R. Jack, "Total Phenolic Content and Antioxidant Activity in Nypa Fructicans Extracts," J. Sustain. Sci. Manag., vol. 10, no. 1, pp. 87-91, 2015.

[11] W. M. A. W. Sabri, M. R. A. R. Asaruddin, A. H. Sukairi, and S. A. T. W. Yusop, "Antioxidant and Cytotoxicity Studies of Nypa fruticans (Nypa Palm Sugar) Extract," Indones. J. Pharm. Sci. Technol., vol. 1, no. 1, pp. 65-69, 2018, doi: 10.15416/IJPST.V1I1.17246.

[12] Imra, K. Tarman, and Desniar, "Aktivitas Antioksidan dan Antibakteri Ekstrak Nipah (Nypa fruticans) Terhadap Vibrio sp . Isolat Kepiting Bakau (Scylla sp.)," J. Pengolah. Has. Perikan. Indones., vol. 19, no. 3, pp. 241-250, 2016 , doi: 10.17844/jphpi.2016.19.3.241.

[13] V. C. Lapitan, K. L. C. Nicolas, and J. Eufemio T. Rasco, "Tissue Culture Technique for Clonal Propagation of Nipa Palm ( Nypa fruticans Wurmb., Arecaceae) from Embryo Culture," Asia Life Sci., vol. 24, no. 1, pp. 111-125, 2015.

[14] N. Prasad et al., "Phytochemicals and Antioxidant Capacity from Nypa fruticans Wurmb. Fruit," Evidence-based Complement. Altern. Med., vol. 2013, pp. 1-9, 2013, doi: $10.1155 / 2013 / 154606$.

[15] N. N., Extraction and Utilization of Anthocyanin Pigments from Jamun (Syzygium Cumini Skeels.). Vellanikkara, 2016.

[16] H. E. Khoo, A. Azlan, S. T. Tang, and S. M. Lim, "Anthocyanidins and Anthocyanins: Colored Pigments as Food, Pharmaceutical Ingredients, and The Potential Health Benefits," Food Nutr. Res., vol. 61, no. 1, 2017, doi: 10.1080/16546628.2017.1361779.

[17] N. M. Saptarini and I. E. Herawati, "Extraction Methods and Varieties Affect Total Anthocyanins Content in Acidified Extract of Papery Skin of Onion(Allium cepa
L.)," Drug Invent. Today, vol. 10, no. 4, pp. 471-474, 2018.

[18] K. D. Rajesh, S. Vasantha, N. V. Rajesh, and A. Panneerselvam, "Qualitative and quantitative phytochemical analysis in four pteridophytes," Int. J. Pharm. Sci. Rev. Res., vol. 27, no. 2, pp. 408-412, 2014.

[19] R. Farida and F. C. Nisa, "Ekstraksi Antosianin Limbah Kulit Manggis Metode Microwave Assisted Extraction (Lama Ekstraksi dan Rasio Bahan: Pelarut)," J. Pangan dan Agroindustri, vol. 3, no. 2, pp. 362-373, 2015, doi: 10.1111/j.15406261.2008.01330.x.

[20] F. Al Mamoori and R. Al Janabi, "Recent Advances in Microwave-Assisted Extraction (MAE) of Medicinal Plants: a Review," Int. Res. J. Pharm., vol. 9, no. 6, pp. 22-29, 2018, doi: $10.7897 / 2230-8407.09684$.

[21] R. Muangrat and P. Saengcharoenrat, "Effect of Processing Conditions of Hot Pressurized Solvent Extraction in Batch Reactor on Anthocyanins of Purple Field Corn," Agric. Eng. Int. CIGR J., vol. 20, no. 2, pp. 173182, 2018.

[22] B. Vayupharp and V. Laksanalamai, "Antioxidant Properties and Color Stability of Anthocyanin Purified Extracts from Thai Waxy Purple Corn Cob," J. Food Nutr. Res., vol. 3, no. 10, pp. 629-636, 2015, doi: 10.12691/jfnr-3-10-2.

[23] H. Ruiz, L. Luna, and P. H. Carranza, "Effect of Solvents and Extraction Methods on Total Anthocyanins, Phenolic Compounds and Antioxidant Capacity of Renealmia alpinia Rottb. Maas Peel," J. Food Technol. Econ. Eng. Phys. Prop. Czech, vol. 35, no. 5, pp. 456-465, 2017, doi: 10.17221/316/2016CJFS.

[24] K. Nayal and A. Onkar, "Optimization of Primary Extraction Conditions of Anthocyanin from Morusrubra L. by Solvent Extraction Method," Babar Int. J. Eng. Technol. Sci. Res., vol. 4, no. 10, 2017.

[25] L. Qadariyah, M. Mahfud, E. Sulistiawati, and P. Swastika, "Natural Dye Extraction from Teak Leves (Tectona Grandis) Using Ultrasound Assisted Extraction Method for Dyeing on Cotton Fabric," MATEC Web Conf., vol. 156, pp. 4-7, 2018, doi: $10.1051 /$ matecconf/201815605004

[26] L. Klavins, J. Kviesis, and M. Klavins, "Comparison of Methods of Extraction of Phenolic Compounds from American Cranberry (Vaccinium macrocarpon L.) Press Residues," Agron. Res., vol. 15, no. Special Issue 2, pp. 1316-1329, 2017.

[27] J. Müller-Maatsch, R. M. Schweiggert, and 
R. Carle, "Adulteration of Anthocyanin and Betalain Based Coloring Foodstuffs with The Textile Dye Reactive Red 195 And Its Detection by Spectrophotometric, Chromatic and HPLC-PDA-MS/MS Analyses," Food Control, vol. 70, pp. 333-338, 2016, doi: 10.1016/j.foodcont.2016.06.012.

[28] F. Ali, Ferawati, and R. Arqomah, "Ekstraksi Zat Warna dari Kelopak Bunga Rosella (Study Pengaruh Konsentrasi Asam Asetat dan Asam Sitrat)," J. Tek. Kim., vol. 19, no. 1, pp. 26-34, 2013.

[29] M. Djaeni, N. Ariani, R. Hidayat, and F. D. Utari, "Ekstraksi Antosianin Dari Kelopak Bunga Rosella (Hibiscus Sabdariffa L.) Berbantu Ultrasonik: Tinjauan Aktivitas Antioksidan," J. Apl. Teknol. Pangan, vol. 6, no. 3, pp. 148-151, 2017, doi: 10.17728/jatp. 236 .

[30] D. Tristantini, A. Ismawati, B. T. Pradana, and J. Gabriel, "Pengujian Aktivitas Antioksidan Menggunakan Metode DPPH pada Daun Tanjung (Minusops elengi L)," in Prosiding Seminar Nasional Teknik Kimia Kejuangan, 2016, pp. 1-7.

[31] A. Santoni, D. Darwis, and S. Syahri, "Isolasi Antosianin dari Buah Pucuk Merah (syzygium campanulatum korth.) Serta Pengujian Antioksidan dan Aplikasi sebagai Pewarna Alami," in Prosiding Semirata FMIPA Universitas Lampung, 2013, pp. 110.

[32] M. Kopjar, M. Orsolic, and V. Pilizota, "Anthocyanins, Phenols, and Antioxidant Activity of Sour Cherry Puree Extracts and Their Stability During Storage," Int. J. Food Prop., vol. 17, no. 6, pp. 1393-1405, 2014, doi: 10.1080/10942912.2012.714027.

[33] F. Susilowati, "Uji Brine Shrimp Lethality Test (BSLT) Ekstrak Etil Asetat Spons Calthropella sp. Asal Zona Intertidal Pantai Krakal Gunung Kidul Yogyakarta," Pharm. J. Islam. Pharm., vol. 1, no. 1, p. 1, 2017, doi: 10.21111/pharmasipha.v1i1.1118.

[34] B. Ginting, T. Barus, L. Marpaung, and P. Simanjuntak, "Uji Toksisitas Ekstrak Daun (Myristica fragrans Houtt) dengan Metode Brine Shrimp Lethality Test (BSLT)," in Prosiding Seminar Nasional Kimia, 2014, pp. 3-6.

[35] T. C. Wallace and M. M. Giusti, "Anthocyanin," Adv. Nutr., vol. 6, no. 5, pp. 620-622, 2015, doi: 10.3945/an.115.009233.Clinical.

[36] BPOM RI, Badan Pengawas Obat dan Makanan Republik Indonesia Nomo 11 Tahun 2019 Tentang Bahan Tambahan Pangan, no. 11. 2019. 